\title{
Crop biodiversity: potential of sustainability indicators and poverty reduction in farming systems in Sudan
}

\author{
Raga Mohamed Elzaki ${ }^{1}$, , Azharia Abdelbaghi Elbushra ${ }^{2}$, Ali Musa Eissa ${ }^{3}$, \\ Shams Eldein Hassab Alla Ahmed ${ }^{4}$ \\ ${ }^{1}$ Department of Rural Economics, Faculty of Animal Production, University of Gezira, Sudan \\ ${ }^{2}$ Department of Consumer Sciences and Agribusiness, College of Agricultural and Food Sciences, King Faisal University - Saudi Arabia \\ ${ }^{3}$ Department of Agricultural Economics and Rural, Natural Resources and Environmental Studies, University of Kordofan- Sudan \\ ${ }^{4}$ Department of Basic Science, College of Veterinary Medicine and Animal Production, Sudan University of Sciences and Technology
}

\section{Email address:}

ragaelzaki@yahoo.co.uk (R. M. Elzaki)

\section{To cite this article:}

Raga Mohamed Elzaki, Azharia Abdelbaghi Elbushra, Ali Musa Eissa, Shams Eldein Hassab Alla Ahmed. Crop Biodiversity: Potential of Sustainability Indicators and Poverty Reduction in Farming Systems in Sudan. American Journal of Agriculture and Forestry.

Vol. 1, No. 4, 2013, pp. 55-62. doi: 10.11648/j.ajaf.20130104.12

\begin{abstract}
This paper presents a theoretical and empirical analysis of the impact of crop biodiversity on poverty reduction and to evaluate the biodiversity of cropping system and its effects on ecological sustainability in rural Sudan. It is based mainly on primary data collected from the household survey. The study focuses on the problem of rural farmers from a broader perspective, among agricultural farming systems in rural Sudan, named as traditional rainfed, irrigated and mechanized rainfed farming system. Poverty line and indicators were analyzed using the Foster Greer and Thorbecke method. The results of the study reveal that the poverty in rural Sudan had been more wide spread and deep in traditional and mechanized farms in contrast with the irrigated farms. In the irrigated farms the farm size is small and the framers are governed by government towards cropping systems and types of crops cultivated. In the mechanized and traditional farms the land size was large, so no rule of what types of crop cultivated. Biodiversity of the three farming systems is differed and concentrated in crop and livestock practices, no aquatic fisheries was practices in farms. The crop diversity is more practices by the non- poor farmers. Results also proved a significant correlation between crop biodiversity indicators with ecological sustainability in the cropping systems. The cultivation of the forage legume is a highly significantly affecting the sustainability in farms. Crop residues management has significantly a positive effect on the water use in the farms. Efficiency and sustainability of crops production would help poor farmers rise out of poverty.
\end{abstract}

Keywords: Biodiversity, Crops, Sustainability Indictors, Poverty

\section{Introduction}

Agriculture in the Sudan is practiced under three major farming systems for crop production, namely irrigated, mechanized (rainfed and commercial) and traditional farming systems. Other farming systems are: livestock, forestry, wildlife and fisheries. The total irrigable land of Sudan was estimated to be 2.79 million ha in 2007 within the Nile River basin in Northern, Khartoum, Gezira, Sennar, Blue Nile and White Nile States. The rainfed traditional farming systems are the main subsistence systems prevalent almost everywhere in the Sudan, accounting for an area of 9.2 million ha, mostly in Kordofan, Darfur, White Nile and Blue Nile States. The commercial mechanized sector extends to about 5.9 million ha in the states of El Gadaref,
Blue Nile, Upper Nile, White Nile, Sennar and Southern Kordofan. Sudan is characterized by climatic, ecological and economical diversity. The vast Majority of the population is poor, with an average per capita income estimated in 2009 at US\$ 2,300. Majority of peoples' livelihood in Sudan are agricultural, pastoral and agropastoral and rely on crop production or livestock rearing for their livelihoods, and those farmers are suffering from food insecurity which is related to inadequate agricultural inputs; insufficient agricultural extension and appropriate technology transfer services; uneven rainfall distribution; a high dependence on traditional, rainfed systems to produce the main staple foods. Cropping systems are based on sorghum, millet and wheat as food crop and groundnut, cotton and sesame as cash crops. Cash 
crops provide income that can be used to supplement family food needs during the months of staple crop shortage. However within the increasing population densities, and the increase in crops inputs price, seek for alternative, but yet productive and sustainable production systems becomes more important.

\subsection{Concept of Agricultural Biodiversity}

Of the 270,000 species of higher plants, about 7,000 species are used in agriculture, but only wheat, rice and maize crop provide half of the world's plant-derived calorie intake [9]

Biodiversity is the variety of living species on this planet and their supporting ecosystems as in [1]. Biodiversity plays a central role in regulating ecosystem processes in ways that ensure the provision of a wide variety of ecosystem goods and services. Whilst these goods and services represent many of the human benefits that are the basis for social and economic development, they are also highly vulnerable to disturbance and disruption by human activities [28]. Agricultural biodiversity, or agrobiodiversity, emphasizes the utility of biological diversity to human wants and needs [32]. The understanding of agricultural biodiversity has developed during the last decades from the recognition of the importance of genetic diversity, particularly for crops and livestock. the agricultural biodiversity refers to all diversity within and among species found in domesticated systems, including wild relatives, interacting species of pollinators, pests, parasites, and other organisms [6].

According to a classification by [5] the crop diversity index belongs to compositional measures of species diversity. The crop biodiversity is defined as a component of agricultural biodiversity, referring to all diversity within and among wild and domesticated species domesticated species, including crop plants that continue to evolve under natural and farmer-selection [22, 3 and 24]

\subsection{Economics Importance of Crop- Biodiversity}

Biodiversity economics refers to the economic analysis of the principles, causes and implications of changes in biological diversity [17]. As in [33] reported that biodiversity economics deals with identifying the social benefits of agro-biodiversity conservation and the social opportunity costs that result from agro-biodiversity loss. According to [31] biodiversity provides at nearly $11 \%$ of the world Gross Domestic Product. Food crop diversity is a key to sustainability and food security. Some literature review analyzed the contribution and importance of crop biodiversity to the mean and the variance of agricultural yields and variance of farm income. [26, 34, 25 and 11]. Crop biodiversity on farms has both inter-specific (among crops) and infra-specific (within a crop) components as in [2]. Crop diversity enables farmers to alleviate climate- and market-related risks, cope with the varying availability of labour, or secure a harvest even if they cannot sow at the normal time.

In agricultural systems, biodiversity may be produced as a positive by-product in addition to marketable output such as cereals. Management practices may have various impacts on biodiversity due to crop rotation, application of chemical inputs and similar choices by the farmer [16].

Biodiversity provides the sustainable balance and equilibrium in agro-ecosystems [10]. For example, it can provide species that can act as natural enemies for biological control or genes for increasing crop resistance to biotic and a biotic stresses.

\section{Problem Statements}

Sudan is rich in its diversity of ecosystems, habitats, species and genetic resources, no coordinated comprehensive surveys have been carried out. However, indicators and observations show that there is a declining trend and diversity loss in many components [30]. Generally Sudan has suffered a number of long and devastating droughts in the past decades, which have undermined food security and are strongly linked to human displacement and related conflicts. The interaction of natural resources, climate and population determines the physical basis for farming systems. During the early stages of development, increased population generally leads to an expansion in cultivated area and, in many cases, conflict between the different users of land and water resources.

Once most good quality land is already exploited, further population increases tend to lead to the intensification of farming systems. As forests and woodlands come under greater pressure, biodiversity is threatened and there may be growing tension between development and conservation goals. These trends have often been exacerbated by colonial and the expansion of agriculture, plus changes in production technologies, which has resulted in a decrease in agro-biodiversity and agricultural ecosystems in recent decades. In natural ecosystems, the widespread application of agrochemicals in agro-ecosystems in form of fertilizers and pesticides has led to a decrease in the diversity of fauna and flora. There has been a considerable reduction in the number of varieties cultivated, which has affected in particular the main cereal crops: wheat, maize and sorghum. A similar loss of biodiversity has occurred among domestic animals. However, modern plant breeding may go some way to reversing this trend by making it easier to maintain genetic material, and by creating a wider gene pool of modern varieties. Farmers in rural sector are characterized by low resource base, low income, low level of human and social capital (education, knowledge and health) and limited access to market and services institutions like credit institutions, extension, plant protection ...etc. crop production and livestock rearing are the main income sources in addition to other non-farm income sources such as selling labor and seasonal migration. The household income is characterized by seasonal fluctuations, which enforce people to engage in many activities like selling fuel 
wood and charcoal and migration...etc. which results in environmental degradation. Soil erosion is the most important aspect of soil degradation. Soil erosion is causing substantial costs to agriculture and these problems are contributing to low agricultural productivity, poverty and food insecurity [14]. The rural poor report distress that stems not only from low consumption but also from ill health and vulnerability.

\section{Objectives of the Study}

The general goal of this study is to explain the poverty cycle of the rural farmers focusing on various farming systems in relation of the crop- biodiversity. The specific objectives set of the study are to:

- Measure poverty line and its indicators in the farming systems.

- Evaluate the biodiversity of cropping systems and its effects on ecological sustainability.

- Investigate the role of crop-biodiversity in poverty reduction and sustainable development in rural Sudan.

\section{Research Methodology}

This study is based mainly on primary data collected from the household survey using questionnaire and group discussion methods (agricultural season 2009/2010). The study covered three production domains from rural Sudan; these are traditional rainfed farms, mechanized rainfed farms and irrigated farms, as these farms rapidly become obvious with dire poverty. Accordingly, the study is planned to cover three States, Kordofan State represents the traditional farms, Blue Nile State represents the mechanized farms and Gezira State represents the irrigated farms.

The data is collected by professional numerators under researcher's supervision using stratified multistage simple random sampling technique to select 600 farm households, the criteria of selection included: From each State 200 households were selected, the researcher's interview with farmers in the crop production. Food and extreme poverty lines were estimated for the rural farmers as follows:

$$
p^{\alpha}=\frac{1}{n} \sum_{1}^{q}\left[\frac{z-y}{z}\right]^{\alpha}
$$

where $\mathrm{n}$ is the total number of individuals under consideration, $\mathrm{q}$ is the total number of poor, $\mathrm{y}$ is the income of the $i^{\text {th }}$ poor individual, $\mathrm{z}$ is the poverty line, and $\alpha$ is a parameter characterizing the degree of poverty aversion i.e. the parameter $\alpha$ determines the precise measure of poverty to be used.

The three poverty indicators (The poverty headcount, poverty gap and squared gap ratios) according to the most widely used method by [15] were estimated.

The poverty headcount ratio: it will be generated when the parameter $\alpha$ equal zero as follows:

$$
H=\frac{q}{n}
$$

Where:

$\mathrm{H}=$ head count ratio, also denoted with $\mathrm{P}^{0}$.

Poverty gap ratio: it will be generated when the parameter $\alpha$ equal one and defined as follows:

$$
P G=\frac{1}{n} \sum_{i=1}^{q}\left[\frac{z-y_{i}}{z}\right]
$$

Where:

$\mathrm{PG}=$ poverty gap ratio, also denoted with $\mathrm{P}^{1}$.

$y_{i}$ is the income of individual (i), often work with household rather than individuals, but the individual still be considered as being equal.

Poverty severity or squared poverty gap:

It obtained when the parameter $\alpha$ equal two as follows:

$$
P S=\frac{1}{n} \sum_{i=1}^{q}\left[\frac{z-y_{i}}{z}\right]^{2}
$$

Where: PS = poverty severity or squared poverty gap, also denoted with $\mathrm{P}^{2}$.

Furthermore the study investigated the impact on the sustainability and poverty reduction in the farms. The cropbiodiversity and it the indicators of crop-biodiversity of the farms are dissimilar from country to one and from farming systems to another, due to variation in natural resources and climate. The indicators used by each country do not have to be the same. Moreover, different countries have a range of ecological, climatic and geophysical differences which may preclude using the same indicator. However, while it may not be possible to have identical indicators at different levels and scales, compatibility is important so that measurements are comparable at these different levels. Various researchers are applied economic analyses of crop biodiversity based either on the farm household model or a model of variety choice that are applied econometrically [3,18 and 27]. As in [10] used the forage legume growing, green manure application, agro-diversity, mean number of cultivated crops and livestock presence in the farm as main indicators of the study conducted in Iran.

In this study the indicators used are forge legume, crop diversity, application of organic fertilizers, chemical fertilizers, pesticides and crop residue management. Moreover the other indicators such as gross margin, total labour and water used were used to develop agricultural sustainability index, act as economical, social and environmental sustainability; respectively.

Crop diversity in this study is different according to the nature of the main crops which, cultivated in the different types of farms. In the irrigated farms it means the percentage of farmers who grow other crops than cotton, wheat, sorghum and groundnut, while in traditional farms it 
means the percentage of farmers who grow other crops than Gum Arabic, watermelon, sorghum and millet. And those in the mechanized farms it means the percentage of farmers grow other crops than sorghum, sesame, millet and groundnut.

Each indicator of crop- biodiversity had a score ranging from zero to a maximum value. The highest and lowest scores represented the most favorable and the worst conditions, respectively.

The explanatory analysis was used in addition to correlation coefficient to show the strength of the relation between crop biodiversity indicators and sustainability of the cropping systems in various farming systems. Additionally the correlation between the household's income and crop-diversity indicators was analyzed.

\section{Results and Discussions}

\subsection{Poverty Line and Indicators}

Table 1 provides a general picture of poverty in rural Sudan by agricultural farming systems. Looking at the food poverty line in the irrigated farms, it is slightly lower than that of the mechanized farms by $0.05 \%$. In contrast, the extreme poverty line in the irrigated farms is lower than that of the mechanized farms by $7.6 \%$, which indicating slightly lower expenditure on food and non- food items in the irrigated farms than that in the mechanized farms. The food poverty line and extreme poverty line in traditional farms is higher in contrast with other two farms.

From Table 1 it is obvious that the head account ratio, poverty gap ratio and poverty square in the traditional farms is high in comparison with the incidence, depth and severity of poverty in other farms during the same periods.

The poverty index in mechanized farms is higher than the irrigated farms by $11.3 \%$ and less than the traditional farms by $12.4 \%$. These results imply that poverty in rural Sudan had been more wide spread and deep in traditional and mechanized farms than in the irrigated farms. Additionally the poverty depth in traditional farms is considerably more than that in the mechanized farms by $28.6 \%$, while the later is more than the irrigated farms by $10.2 \%$. Also, the results show that the poverty severity in the traditional farms is higher than the mechanized farms by $40 \%$, while in the mechanized farms is further than the irrigated farms poverty by $9 \%$. These results reveal that, when the traditional and mechanized farms their labour farms wage failed to absorb rural migrants from neighboring civil war regions, the incidence of rural poverty in those regions started to emerge and grow faster than those of the safe regions. This suggests that the incidence of poverty in rural traditional farms and rural mechanized farms are considerably higher than the rural irrigated poverty.

Table 1: Poverty Incidence of the Rural Farmers in Farming Systems in Sudan

\begin{tabular}{llll}
\hline Poverty measures & \multicolumn{2}{c}{ Type of farming systems } & Mechanized \\
\hline Food poverty line*(\$) & Irrigated & Traditional & 0.17 \\
Extreme poverty line*(\$) & 0.14 & 0.34 & 0.21 \\
Head account ratio (\%) & 0.16 & 0.41 & 85.4 \\
Poverty gap ratio (\%) & 74.1 & 97.8 & 65.1 \\
Squared gap ratio & 54.9 & 93.7 & 49.6 \\
\hline
\end{tabular}

Source: authors' calculations. * These were estimated in per day per one person

As a comparison between the proportions of the poor and non-poor farmers in the three farms it is found that the highest number of the rural poor people is found in the traditional farms which amounted to $94 \%$ (Table 2), is mainly attributable to the recurrent droughts in this areas and to recent up cropping of civil in the south and western parts of the greater Kordofan region. The mechanized farms had high estimated percentage among the rural poor $(75.5 \%)$ and the one prominent reason is the nearby civil war in the State and south Sudan. Although the central region of Sudan was peaceful (no civil war violence this area), the number of the rural poor to some extent is high, which is more than half of the total surveyed households $(70.0 \%)$. This result almost is in agreement with that of as in [12], who estimated the number of rural poor in this State to be about $72.4 \%$. The main reason behind the high percentage of the rural poor in the irrigated farms is attributable to failed agricultural seasons during the last few years caused by scarcity of the rains and shortage of agricultural credit. Tenants' access to credit and/or off-farm income may determine whether and how much they are able to purchase of inputs. Without sufficient access to credit (and even with it), poverty may prevent tenants from taking advantage of profitable opportunities to use resources, due to financial constraints as well as extreme risk aversion [21].

In general, the results of the study clarified that, proportion of the rural non-poor tenants among the total surveyed households has been considerably low in all farms (Table 2). 
Table 2: Proportions of the Rural Non-Poor and Poor Households in the Agricultural Farming Systems in Sudan

\begin{tabular}{|c|c|c|c|c|c|c|}
\hline \multirow{2}{*}{ Poverty status } & \multicolumn{2}{|c|}{ Mechanized farms } & \multicolumn{2}{|l|}{ Irrigated farms } & \multicolumn{2}{|c|}{ Traditional farms } \\
\hline & No. of farmers & $\%$ & No. of farmers & $\%$ & No. of farmers & $\%$ \\
\hline Non- poor & 49 & 24.5 & 60 & 30.0 & 11 & 5.5 \\
\hline Poor & 151 & 75.5 & 140 & 70.0 & 189 & 94.5 \\
\hline Total & 200 & 100 & 200 & 100.0 & 200 & 100.0 \\
\hline
\end{tabular}

Source: Field survey, 2009/2010

\subsection{Crops production and Functions}

The major crops produced by the rural farmers in the irrigated farms are cotton, sorghum, groundnut and vegetables. In the irrigated farms the framers are governed by Gezira board towards cropping systems and types of crops cultivated. In the mechanized and traditional farms the land size was large, so no rule of what types of crop cultivated. The main crops produce in the mechanized farms were sorghum, millet, groundnut and sesame. The most important crops for exports and domestic consumption produced in the traditional farms are millet, sorghum, groundnut, sesame, Roselle, watermelon seeds, vegetables (okra, onions, and legumes) and Gum Arabic.

The research results reveals that the irrigated farms are mainly depend on the crops production to derive the households' income (64\%). The bulk of income comes from cotton production as the main cash crop and $25 \%$ of the income is derived from the livestock production. This result is confirmed by [13], she found that $47 \%$ of the income of tenants household is derived from crops in the irrigated scheme, while contribution of livestock enterprise to total household income is $36 \%$.

The main source of income in the traditional farms is derived from the crop production (52\%) and livestock production $(45 \%)$. In the mechanized farms the case is differed, the households depend on the non-agricultural income mainly (54\%), where the crops production shared about $33 \%$ from the total income and the livestock production shared with $13 \%$. This may be due to migration of the some members of the household's to the urban areas and bordering States for job seeking due to civil wars in the last decades.

In all farms the crops production provides funds for investment in other non agricultural and agricultural enterprises and most of domestic needs were met by the income generated from crops production.

Since majority of Sudanese population depend mainly on the sorghum crop (in the irrigated and mechanized farming system) and millet products (in the traditional farming system) as the main food stuff in their meals, the study results reveal that, the most profitable crops of the rural farmers are vegetables (in the irrigated farms), groundnut (in the mechanized farms) and the watermelon seeds (in the traditional farms).

Food crops grown by many households provide the food security and means of survival while waiting for the next season. Majority of food crops production is used for home-consumption both for human or livestock feed, these comprised as $90 \%$ in irrigated, $95 \%$ in traditional and $92 \%$ in mechanized farms.

In traditional and mechanized farms a large proportion of land is under watermelon and maize production; respectively and therefore little portion are spared for food crop. In many crops farms no animal manure was used. The manure is used for building paints and some time used for cooking in the field and home-side. The crops mainly depend on the chemical fertilizers.

\subsection{Biodiversity Indicators of Crop Species in the Farming Systems}

Crop species diversity of the cropping system of the all farms is shown in Table $3.45 \%$ of the farmers in the irrigated farms are cultivated others crops than cotton, wheat, sorghum and groundnut (these cultivated crops named sunflower, $14 \%$, and vegetables, $65 \%$,). $15 \%$ of farmers grow wheat in the irrigated farms. The area of wheat cultivation in the irrigated farms was declined in the last decays, this is mainly due to variation in the environment, so the global climate change was significantly affect the wheat production in Sudan.

Majority of farmers in the traditional farms (78\%) and mechanized farms $(80 \%)$ cultivated others crops than the main crops mentioned above. These named as sunflowers $(89 \%)$, vegetables $(54 \%)$, okra $(67 \%)$ and rosella $(45 \%)$ in the traditional farms and vegetables $(56 \%)$ and cotton $(14 \%)$ in the mechanized farms.

Table 3: Percentage of crop-Biodiversity Indicators in the Farming Systems

\begin{tabular}{llll}
\hline Crop- biodiversity indicators & $\begin{array}{l}\text { Type of farming systems } \\
\text { Irrigated }\end{array}$ & Traditional & Mechanized \\
\hline Forge legume & 0 & 16 & 18 \\
Crop diversity & 45 & 78 & 80 \\
Application of organic fertilizers & 0 & 56 & 45 \\
Chemical fertilizers & 98 & 65 & 70 \\
Pesticides & 80 & 70 & 78 \\
Crop residues management & 78 & 87 & 80 \\
\hline
\end{tabular}

Source: field survey, 2009/2010 
In the irrigated farm no forge legume is cultivated in addition no application of organic manure is used in the farms. $16 \%$ and $18 \%$ of the farmers are introduce forage legumes into their crops rotation in the traditional and mechanized; respectively, so there are no rule governing the crop cultivation in these areas. As in [20] reported that there is a direct correlation between crop diversity and pest and disease control. Majority of the farmers are used the chemical fertilizers $(98 \%$ in irrigated, $65 \%$ in traditional and $79 \%$ in the mechanized farms) and pesticides $(80 \%$ in irrigated, $70 \%$ in traditional and $78 \%$ in mechanized farms) in their farms. The used of crops residue are normally associated with the owned of livestock, so majority of farmers feed their animal from crops residue. No credit was provided in the traditional and mechanized farm which may play a pivotal role in determining crop biodiversity.

\section{Impact of crop-Biodiversity on Sustainability Indicators}

Sustainability' means different things over different timeframes and to different stakeholders [2 and Morse, 1999). There is a significant positive correlation between crop species diversity with sustainability in all farming systems (Table 4). In case of gross margin and labour use (as sustainability indicators) the used of chemicals fertilizers have a positive correlation with sustainability in irrigated and mechanized farms, however it has a negative relation in the traditional farms, that mainly due to availability of finance in the irrigated and mechanized farms.

The cultivation of the forage legume is a highly significantly affecting the sustainability in all farming systems. Many researchers reported there are positive effects of growing legumes crops on the sustainability of agro-ecosystems [29 and 4]. The results of [19] also indicated that green manure improved soil characteristics and increased rice yield, while as in [10] found that relationship between growing green manure and sustainability was not significant. Crop residues management has significantly a positive effect on the water use in all farms.

Table 4: Correlation Coefficient of crop Biodiversity and Sustainability indicators in Farming Systems in Sudan

\begin{tabular}{|c|c|c|c|c|c|c|c|c|c|}
\hline \multirow{2}{*}{ Crop-biodiversity indicators } & \multicolumn{3}{|c|}{ Irrigated } & \multicolumn{3}{|c|}{ Traditional } & \multicolumn{3}{|c|}{ Mechanized } \\
\hline & GM & $\mathbf{L U}$ & $\mathbf{W U}$ & GM & $\mathbf{L U}$ & $\mathbf{W U}$ & GM & $\mathbf{L U}$ & $\mathbf{W U}$ \\
\hline Forge legume & $0.013 *$ & $0.53 *$ & $0.57 * *$ & $0.23 *$ & $0.46^{* *}$ & $0.92 *$ & $0.67 *$ & $0.89 *$ & $0.59^{*}$ \\
\hline Crop diversity & $0.56^{*}$ & $0.86^{*}$ & $0.52 *$ & $0.66^{*}$ & $0.78 *$ & $0.66^{*}$ & $0.034 * *$ & 0.054 & $0.52 *$ \\
\hline Application of organic fertilizers & 0.01 & -0.31 & $0.61 * *$ & $0.21 *$ & $-0.67 *$ & $-0.51 *$ & $0.34 *$ & $0.57 * *$ & $0.34 *$ \\
\hline Chemical fertilizers & $0.78 * *$ & $-0.45 *$ & 0.023 & $-0.81 * *$ & $-0.67 * *$ & -0.14 & $0.15^{*}$ & 0.13 & 0.18 \\
\hline Pesticides & $0.67 * *$ & 0.012 & 0.12 & $0.56 * *$ & $0.89 *$ & 0.14 & 0.34 & $0.64 * *$ & 0.34 \\
\hline Crop residues management & $-0.45^{*}$ & $0.56^{*}$ & $-0.59 *$ & $0.34 *$ & 0.013 & $0.89 * *$ & 0.12 & 0.34 & $0.71 *$ \\
\hline
\end{tabular}

GM: gross margin indicator as economical factor, LU: labour use as social factor and WU: water use as environmental factor.

* Correlation is significant at the 0.05 level (2-tailed).

** Correlation is significant at the o.ol level (2-tailed).

\section{Impact of crop - diversity on Poverty Reduction}

There is some evidence that agricultural biodiversity; particularly plant diversity is concentrated in areas of poverty. In general, there is more plant diversity in developing countries than in developed countries; further, plant diversity tends to be concentrated in the poorest, least developed regions of countries. This has led to a view that development and agricultural biodiversity are in opposition, and that economic development should involve the 'conversion' of diverse areas to 'more productive' areas [8].

The study reveals that the crop diversity is more practices by the non- poor farmers in all farms $(68 \%$ of the non- poor cultivated more than two crops). In the irrigated farms about $56 \%$ and $78 \%$ of the poor farmers can't cultivated the cotton (for financial problems) and wheat crops (for environmental changed). Cotton crop is considered as the main cash crop in the cropping systems of Sudan. Within any given community, crop diversity is often handled more by richer farmers [7]. Table 5 shows that the non- poor farmers have highly more significantly positive correlation between the cropdiversity indicators and their income than the poor farmer, exceptional for the farmers in the traditional farms in case of the crop residues management in the farm..

There is a positive relationship between agricultural biodiversity and household incomes; richer households tend to grow more varieties of different crops than poorer households whose livelihood depend on returns from farms [23] 
Table 5: Correlation Coefficient of crop-Biodiversity indicators and households income in the Farming Systems in Sudan

\begin{tabular}{|c|c|c|c|c|c|c|}
\hline \multirow{2}{*}{$\begin{array}{l}\text { Crop- biodiversity } \\
\text { indicators }\end{array}$} & \multirow{2}{*}{$\begin{array}{l}\text { Irrigated } \\
\text { Non-poor } \\
\text { farmers }\end{array}$} & \multirow[b]{2}{*}{ Poor farmers } & \multicolumn{2}{|l|}{ Traditional } & \multicolumn{2}{|l|}{ Mechanized } \\
\hline & & & Non-poor farmers & Poor farmers & Non-poor farmers & Poor farmers \\
\hline Forge legume & .023 & .011 & .001 & .025 & $.045^{*}$ & .012 \\
\hline Crop diversity & $.89^{* *}$ & $0.25^{*}$ & $.82 * *$ & $.72 * *$ & $.78 * *$ & $.16^{* *}$ \\
\hline $\begin{array}{l}\text { Application of organic } \\
\text { fertilizers }\end{array}$ & 0.25 & 0.33 & $0.13 *$ & 0.14 & $0.64 *$ & 0.23 \\
\hline Chemical fertilizers & $0.57^{*}$ & $0.14^{*}$ & $0.34^{*}$ & 0.12 & -0.15 & 0.13 \\
\hline Pesticides & $0.78^{*}$ & $0.14 * *$ & 0.03 & 0.17 & $0.65^{*}$ & $0.16^{* *}$ \\
\hline $\begin{array}{l}\text { Crop residues } \\
\text { management }\end{array}$ & $0.67 * *$ & $0.12 * *$ & $0.16^{* *}$ & $0.11 *$ & $0.82 *$ & $0.19^{*}$ \\
\hline
\end{tabular}

Source: authors' calculations

* Correlation is significant at the o.05 level (2-tailed).

** Correlation is significant at the o.ol level (2-tailed).

\section{Conclusions and Policy Implications}

- The incidence of poverty in rural traditional farms and rural mechanized farms are considerably emerge and grow faster and higher than the rural irrigated poverty.

- Higher proportion of poor farmers are concentrated in the traditional farms.

- The main source of the household's income is derived from crops and livestock production in all farming systems. There is a positive relationship between agricultural biodiversity and household incomes.

- The most profitable crops of the rural poor are vegetables crop (in the irrigated farms), groundnut crop (in the mechanized farms) and the watermelon seeds (in the traditional farms).

- There is a significant positive correlation between cropbiodiversity indicators with ecological sustainability in the cropping systems, particularly between crop species diversity with sustainability in all farming systems. The used of chemicals fertilizers have appositive correlation with sustainability in irrigated and mechanized farms while it reported a negative correlation in the traditional farms.

- Efficiency and sustainability of crops production would help poor farmers rise out of poverty.

- Introducing the legume crop in crop rotation will reduce fertilizer application, increase the sustainability of farming systems and enhances biodiversity in agroecosystems.

- Shockingly, the impact or intervention of agricultural policies on agro-biodiversity (both crop and livestock) has been ignored.

- Opportunities for using agricultural biodiversity to reduce poverty by strengthen the extension services through awareness the farmers about using intensive technology to develop their inputs and increasing their outputs and strengthening of local institutions and universities by studying the biodiversity and its effect as major course.

\section{References}

[1] Anthony, V.(2011). Crop Biodiversity Definitions, importance and threats. Syngenta Foundation 10th Anniversary Symposium

[2] Bell, S. and Morse, S. (1999) Sustainability indicators: Measuring the immeasurable. London: Earthscan.

[3] Brush, S., J.E. Taylor and M.R. Bellon. (1992). Biological diversity and technology adoption in Andean potato agriculture. Journal of Development Economics 39:365-387.

[4] Caballero, R. (1993). An experts' survey on the role of forage legumes in arable cropping systems of the Mediterranean area. J. Sust. Agric., 3: 133-154.

[5] Callicott, J.B., Crowder, L.B. and Mumford, M.R. (1999). Current normative concepts in conservation. Conservation Biology 13: 22-35.

[6] Cassman, K. G., S. Wood, P. S. Choo, C. Cooper, C. Devendra, J. Dixon, J. Gaskell, S. Khan, R. Lal, L. Lipper, J. Pretty, J. Primavera, N. Ramankutty, E. Viglizzo, K. Weibe, S. Kadungure, N. Kanbar, Z. Khan, R. Leakey, S. Porter, K. Sebastian, and R. Tharme. (2005). Cultivated Systems. In Millennium Ecosystem Assessment. Condition Working Group Report. Washington D.C.: Island Press.

[7] Cromwell, E. Kambewa, P; Mwanza, R. and Chirwa R. with Kwera Development Centre, (2000). Impact Assessment Using Participatory Approaches: 'Starter Pack' And Sustainable Agriculture In Malawi. The Agricultural Research and Extension Network. Department for International Development (DFID). London, UK.

[8] Cromwell, E.; Cooper, D. and Mulvany, P. (1997a). Agriculture, biodiversity and Livelihoods: Issues and Entry Points For Development Agencies. The Agricultural Research and Extension Network. Department for International Development (DFID). London, UK.

[9] Cromwell, E; Cooper, D. and Mulvany, P. (1997). Agriculture, Biodiversity and Livelihoods: Issues And Entry Points For Development Agencies. Overseas Development 
Institute, Westminster Bridge Road. London

[10] Damghani, A. M; Koocheki, A. and Moghaddam, P.R. and M.N. Mohallati (2007). Evaluation of Agrobiodiversity and its Effects on the Sustainability of a Wheat-Cotton Cropping System in Khorassan. Department of Agroecology, Environmental Sciences Research Institute, Shahid Beheshti University

[11] Di Falco, S., Perrings C.(2003). Crop Genetic Diversity, Productivity and Stability of Agro-ecosystems: A Theoretical and Empirical Investigation. Scottish Journal of Political Economy, Vol.50. no..2.

[12] Elsheikh, S. and Siwar, C. (2004): Tenant Households and Poverty in the Gezira Irrigated Area, Sudan: Analysis and Implications. Faculty of Economics, University Kebangsaan, Selangor, Malaysia

[13] Elzaki, R.M (2005). The feasibility of integration of livestock production in irrigated agriculture in Sudan. Gezira scheme. Ph.D. thesis. Faculty of Agriculture. University of Khartoum. Sudan.

[14] FAO (2005). Integrating environmental and economic accounting at the farm level. Accounting for changes in the fertility of cultivated land. Food and agriculture organization of the united nations. Rome, 2005

[15] Foster, J., Greer, J. and E. Thorbecke, (1984). A New Class of Decomposable Poverty Measures. Econometrical, vol. 51, no. 1.

[16] Huhtala, A. and Sipiläinen, T. (2009). Do the opportunity costs of providing crop diversity differ between organic and conventional farms? The case of Finnish agriculture. MTT Agrifood Research Finland, Latokartanonkaari Helsinki, Finland.

[17] Kontoleon, A., Pascual, U. and Smale, M. (2009) 'Agrobiodiversity for economic development: what do we know?', in A. Kontoleon, U. Pascual and M. Smale (eds). Agro-biodiversity Conservation and Economic Development, Routledge, London and New York, pp1-24.

[18] Meng, E. (1997). Land allocation decisions and in situ conservation of crop genetic resources: the case of wheat landraces in Turkey. Doctoral dissertation. University of California-Davis, Davis.

[19] Mubarik, A. (1999). Evaluation of green manure Technology in tropical lowland rice systems. Field Crop Res., 61: 61-78.

[20] Nankya, R. (2012). The Conservation of Diversity versus the Conservation of Poverty. Programe of Crop diversity to reduce pest and diseases. Kampala, Uganda.

[21] Pender, J. (1999). Rural Population Growth, Agricultural Change and Natural Resource Management in Developing Countries: A review of Hypotheses and some Evidence from Honduras. Environment and Production Technology Division. International Food Policy Research Institute, Washington, U.S.A.
[22] Qualset, C.O., McGuire, P.E. and Warburton, M.L. (1995). 'Agrobiodiversity': key to agricultural productivity. California Agriculture 49(6).

[23] Redford, K and Agrawal, A (2006) Poverty, Development, And Biodiversity Conservation: Shooting in the Dark? Working Paper No. 26 March 2006

[24] Smale, M., E. Meng, J.P. Brennan, Ruifa Hu, (2003a). Determinants of spatial diversity in modern wheat: examples from Australia and China. Agricultural Economics, 28.

[25] Smale, M., E. Meng, J.P. Brennan, Ruifa Hu, (2003). Determinants of spatial diversity in modern wheat: examples from Australia and China. Agricultural Economics, 28.

[26] Smale, M., Hartell, J., Heisey, P.W., Senauer, B., (1998). The contribution of genetic resources and diversity to wheat production in the Punjab of Pakistan. American Journal of Agricultural Economics, 80.

[27] Smale, M., M. Bellon, and A. Aguirre. (2001). Maize diversity, variety attributes, and Farmers' choices in Southeastern Guanajuato, Mexico. Economic Development and Cultural Change 50(1):201-225.

[28] Tilman.D. (2000) Causes, consequences and ethics of biodiversity. Nature Insight 405 (No. 6783, 11 May) 208211.

[29] Torknezhad, A., D. Mazaheri, H. Heydari Sharifabad and A. Ghalavand (1999). Evaluation of annual medics' efficiency on fixing biological nitrogen and its implications in sustainable agricultural systems. Pajouhesh-va-sazandegi, 43: $22-25$.

[30] UNDP, (2005). Sudan - Details. Status and Trends of Biodiversity Overview. http://www.cbd.int/countries/profile.shtml?country=sd\#statu

[31] USAID. $2004 . \quad$ Biodiversity. http://www.usaid.gov/our_work/environment/biodiversity/

[32] Walcott, J. (2004). Agriculture and biodiversity: connections for sustainable development. Bureau of Rural Sciences, Canberra.

[33] Wale,E.; Drucker, A. G. and Zander, K.K.(2011). The Economics of Managing Crop Diversity On-farm. Case studies from the Genetic Resources Policy Initiative. Earthscan Ltd, Dunstan House, London, UK.

[34] Widawsky, D., and S. Rozelle, (1998). Varietal diversity and yield variability in Chinese rice production, in M. Smale ed., Farmers, Gene Banks, and Crop Breeding, Kluwer, Boston.

[35] Wood, D. and Lenné, J.M. (eds) (1999). Agrobiodiversity: characterization, utilization and management. CABI, Wallingford. 